\title{
COMPARISON OF DERIVED CENTRAL AORTIC PRESSURE VS CUFF PERIPHERAL PRESSURE
}

\author{
K.V. Siva Krishna,M. Ravi Kiran, Indrani Garre
}

\begin{abstract}
:
Background: Emerging evidence favours Central aortic pressure as a better correlate of cardiovascular events than peripheral BP recorded with sphygmomanometer. Noninvasive devices to calculate the derived central aortic pressures are available now. We want to see the difference of $B P$ between derived central BP vs manual recorded BP and to see whether these BP values are consistent among different sexes and age groups.

Materials and methods: In the present study 63 consecutive patients both male and female who attended the cardiology outpatient department were studied. In all these patients blood pressure was recorded both manually by sphygmomanometer and by Mobil-O-Graph ${ }^{\circledR}$ Pulse Wave Analyser (ARC Solver). The Mobil-O-Graph ${ }^{\circledR}$ system works on the oscillometric recording of pulse waves at the brachial artery site. We recorded the $B P$ in sitting posture. We compared the derived central, manual and device measured $B P$, cardiac output, and pulse wave velocity between both genders.

Results: Among the study population (63 patients) 20 were females and 43 were males with mean age of 58.92 $\pm 10.9 \mathrm{yrs}$. The mean systolic and diastolic manually recorded peripheral $B P$ was $127.25 \pm 19.89$ and $79.25 \pm 8.58 \mathrm{~mm}$ of $\mathrm{Hg}$ respectively, whereas the mean peripheral SBP and DBP recorded by the device was $129.40+21.21$ and $81.56 \pm 12.83 \mathrm{~mm}$ of $\mathrm{Hg}$ respectively (comparable $p=0.6,0.2$ ). The mean central aortic $S B P \& D B P$ recorded by the device was $117.37 \pm 19.17$ and $81.67 \pm 13.04 \mathrm{~mm}$ of $\mathrm{Hg}$ with the mean pulse wave velocity of $8.392+1.741 \mathrm{~m} / \mathrm{sec}$. There was a statistically significant difference in the central aortic SBP and manual SBP ( $p=0.005)$, whereas the difference in DBP was not statistically significant $(p=0.2)$. There is no statistically significant difference in the central and peripheral SBP and DBP recorded by the device among males and females. The device derived parameters including cardiac output, pulse wave velocity also did not show significant difference in both sexes.

Conclusion: Derived central aortic systolic pressure recorded by the device is lower than the manually recorded pressure
\end{abstract}

Article received on 01 JAN2017, published on 31JAN 2017.

K.V. Siva Krishna ${ }^{1}$,M. Ravi Kiran ${ }^{1}$,Indrani Garre ${ }^{2}$

${ }^{1}$ Senior Resident, Department of Cardiology, NIMS, India

${ }^{2} \mathrm{PhD}$ student, Department of Cardiology, NIMS, India

Corresponding author: K.V. Siva Krishna

Email: venkatasivakrishna.k@gmail.com whereas there was no difference in diastolic BP. There is no difference in these $B P$ recordings between the genders.

Keywords: Central blood pressure (BP), Peripheral BP, Cuff BP.

\section{INTRODUCTION:}

The brachial cuff sphygmomanometer was introduced into medical practice well over 100 years ago, enabling the routine, non-invasive, measurement of arterial blood pressure. The most recent Global Burden of Disease report identified hypertension as the leading cause of death and disability worldwide [1].Data from over 50 years of randomized controlled trials clearly demonstrate that lowering brachial pressure, in hypertensive individuals, substantially reduces cardiovascular events [2]. So measurement of brachial blood pressure has become embedded in routine clinical assessment throughout the world. Recent evidence suggests that central pressure is also more strongly related to future cardiovascular events $[4,5,6]$ than brachial pressure, and responds differently to certain drugs. The major driving force for the continued use of brachial blood pressure has been its ease of measurement, and the wide variety of devices available for clinical use. Central pressure assessment and accuracy have to be standardized, as it has been for brachial pressure assessment with oscillometric devices. Arterial pressure varies continuously over the cardiac cycle, but in clinical practice, only systolic and diastolic pressures are routinely reported. These are invariably measured in the brachial artery using cuff sphygmomanometer.

Although diastolic and mean arterial pressures are relatively constant, systolic pressure may be up to 40 $\mathrm{mmHg}$ higher in the brachial artery than in the aorta $[7,8,9]$. This phenomenon of systolic pressure amplification arises principally because of an increase in arterial stiffness moving away from the heart. As the pressure wave travels from the highly elastic central arteries to the stiffer brachial artery, the upper portion of the wave becomes narrower, the systolic peak becomes more prominent, and systolic pressure increase. The potential clinical relevance of this variability in 
amplification became evident when the aortic and brachial pressure was evaluated in a cohort of 10000 volunteers [10].This will have important clinical implications if central pressure turns out to be a better predictor of cardiovascular risk, because it suggests that, currently may be some subjects with relatively low central pressures are being treated, and some individuals with elevated central pressures are not being treated, because they have brachial systolic pressures under current treatment thresholds. As central aortic pressure has been proven to be a better predictor of cardiovascular events routine monitoring and treatment of central aortic pressure noninvasively plays an important role inprevention of cardiovascular events. In the present study, we hypothesized central aortic systolic pressure to be lower than brachial artery pressure and we want to observe whether the machine derived values are consistent across different populations.

\section{MATERIALS AND METHODS:}

In the present study, 63 patients who come to cardiology Out Patient Department (OPD) were included. Blood pressure was measured by a conventional method in the right upper limb in sitting posture with patient seated comfortably, with back supported, legs uncrossed, and upper arm bared and arm supported at the level of the heart with an appropriate sized cuff bladder covering $80 \%$ of arm circumference. Mercury column has been deflated at 2 to $3 \mathrm{~mm}$ per second and the first and last audible korotkoff's sounds were recorded as systolic and diastolic pressures respectively [25]. The non-invasive central aortic pressure was measured by a device MobilO-Graph ${ }^{\circledR}$ Pulse Wave Analyser (ARC Solver) which simultaneously records the peripheral pressure, cardiac output, heart rate, pulse wave velocity, cardiac index and stroke volume. The device is one of the most popular long-term blood pressure monitors for the medical practice or clinic. It works on the oscillometric recording of pulse waves at the brachial artery site. According to the device data, the accuracy of the device is $+/-3 \mathrm{mmHg}$ in the range indicated.

The recordings of central aortic pressures were compared with conventional BP recording; the device calculated pressures are compared in both sexes. The demographic data, medication history, and routine clinical data was taken from all the patients

Statistical analysis: Statistical analysis was performed using Minitab version 17. Continuous variables were expressed as mean+standard deviation (SD) with range. Categorical variables were expressed as percentages.

\section{RESULTS:}

In the study population 20 were female and 43 were male. The mean age of the study population is $58.9 \pm 10.9$ years. The mean systolic and diastolic manually recorded peripheral $\mathrm{BP}$ was $127.3 \pm 19.9 \mathrm{~mm}$ of $\mathrm{Hg}$ and $79.25 \pm 8.58 \mathrm{~mm}$ of $\mathrm{Hg}$ respectively, whereas the mean peripheral SBP and DBP recorded by the device was $129.4 \pm 21.2 \mathrm{~mm}$ of $\mathrm{Hg}$ and $81.6 \pm 12.8 \mathrm{~mm}$ of $\mathrm{Hg}$ respectively. The mean central aortic SBP \& DBP recorded by the device was $117.4 \pm 19.2 \mathrm{~mm}$ of $\mathrm{Hg}$ and $81.7 \pm 13.04 \mathrm{~mm}$ of $\mathrm{Hg}$. The mean pulse wave velocity was $8.4 \pm 1.7 \mathrm{~m} / \mathrm{s}$. The baseline data obtained is shown in Table 1.

Table 1: Baseline data of all patients

\begin{tabular}{|l|l|l|l|l|}
\hline Variable & Mean & StDev & Minimum & Maximum \\
\hline Age (yrs) & 58.9 & 10.8 & 33 & 81 \\
\hline $\begin{array}{l}\text { Systolic BP } \\
\text { (mm of Hg) }\end{array}$ & 129.4 & 21.2 & 94 & 192 \\
\hline $\begin{array}{l}\text { Diastolic BP } \\
\text { (mm of Hg) }\end{array}$ & 81.6 & 12.8 & 52 & 119 \\
\hline $\begin{array}{l}\text { Systolic CABP } \\
\text { (mm of Hg) }\end{array}$ & 117.4 & 19.2 & 89 & 176 \\
\hline $\begin{array}{l}\text { Diastolic CABP } \\
\text { (mm of Hg) }\end{array}$ & 81.7 & 13.04 & 53 & 121 \\
\hline HR (/min) & 79.7 & 15.1 & 48 & 121 \\
\hline PWV (m/s) & 8.4 & 1.7 & 5.5 & 12.1 \\
\hline $\begin{array}{l}\text { MAP } \\
\text { (mmof Hg) }\end{array}$ & 102.2 & 16.2 & 71 & 152 \\
\hline PP (mm of Hg) & 46.7 & 15.3 & 23 & 101 \\
\hline CO (L/min) & 4.2 & 0.9 & 2 & 6.4 \\
\hline SV (ml) & 54.5 & 9.3 & 34 & 80 \\
\hline CI (L/min/m $\left.{ }^{2}\right)$ & 2.52 & 0.57 & 1.4 & 4 \\
\hline $\begin{array}{l}\text { MANUAL } \\
\text { systolic BP (mm } \\
\text { of Hg) }\end{array}$ & 127.3 & 19.9 & 100 & 190 \\
\hline $\begin{array}{l}\text { MANUAL } \\
\text { diastolic BP (mm } \\
\text { of Hg) }\end{array}$ & 79.3 & 8.6 & 60 & 100 \\
\hline
\end{tabular}


The data obtained is analyzed. The difference between the machine derived central aortic and peripheral systolic and diastolic pressures and manual systolic and diastolic pressures were obtained. Scatter plot was drawn between these variables. In Fig 1 the scatter plot between manual and central blood pressure is showing a linear correlation and in Fig 2 similar correlations were found between machine peripheral and manual blood pressure.

Fig 1: Scatter plot of machine peripheral BP vs manual BP.

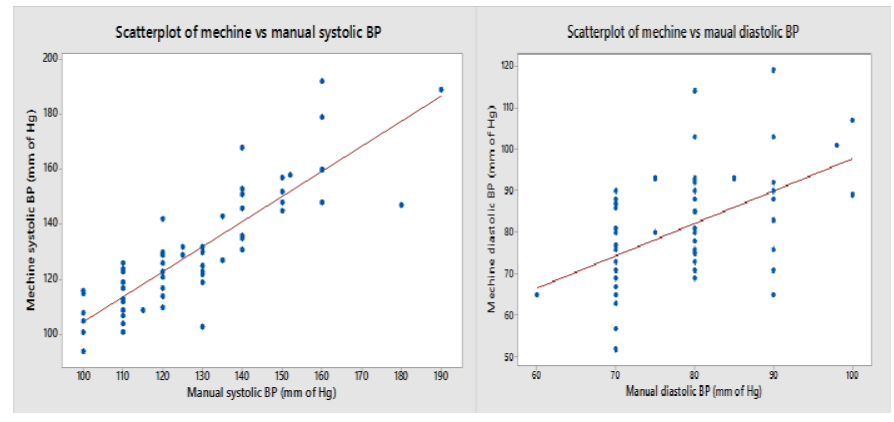

Fig 2: Boxplot for machine and manual recorded systolic and diastolic blood pressures with $\mathrm{p}$ values.

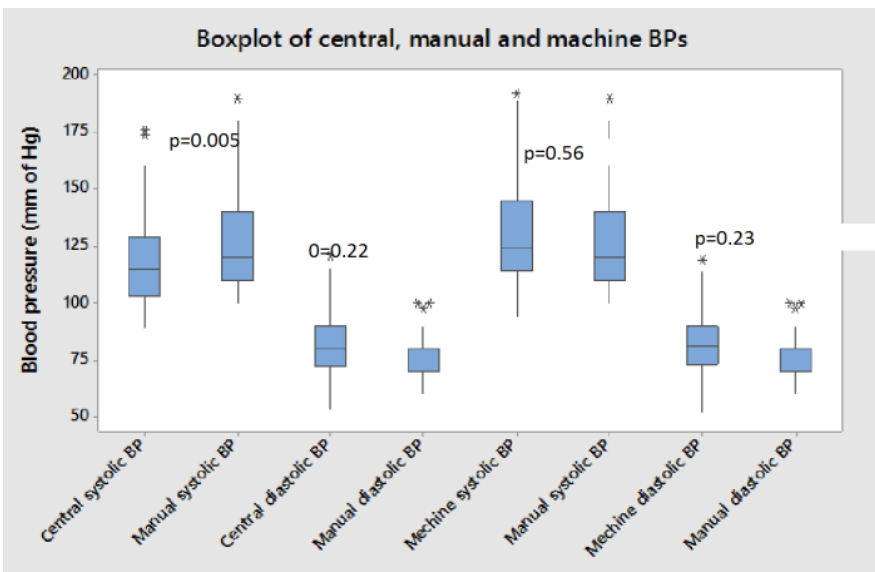

There was a statistically significant difference in the central aortic SBP and manual SBP with a $\mathrm{p}$ value of 0.005 , whereas the difference in DBP was not statistically significant with $\mathrm{p}$ value of 0.221 . The difference in the peripheral BP recorded by the device and manual recording did not show statistically significant difference for both SBP and DBP ( $p=0.56,0.23$ respectively) (Table 2, Fig 4).
Table 2: Two-sample $t$ Test for systolic CABP vs MANUAL systolic BP.

\begin{tabular}{|c|c|c|c|c|c|}
\hline & $\mathrm{N}$ & Mean & St dev & $\begin{array}{l}\text { SE } \\
\text { Mean }\end{array}$ & \multirow{3}{*}{$\begin{array}{l}p \\
\text { Value }= \\
0.005\end{array}$} \\
\hline $\begin{array}{l}\text { Systolic } \\
\text { CABP }\end{array}$ & 63 & 117.4 & 19.2 & 2.4 & \\
\hline $\begin{array}{l}\text { Manual } \\
\text { systolic } \\
\text { BP }\end{array}$ & 63 & 127.3 & 19.9 & 2.5 & \\
\hline
\end{tabular}

Fig 3: Interval plot of machine derived central and recorded peripheral blood pressure in males and females.

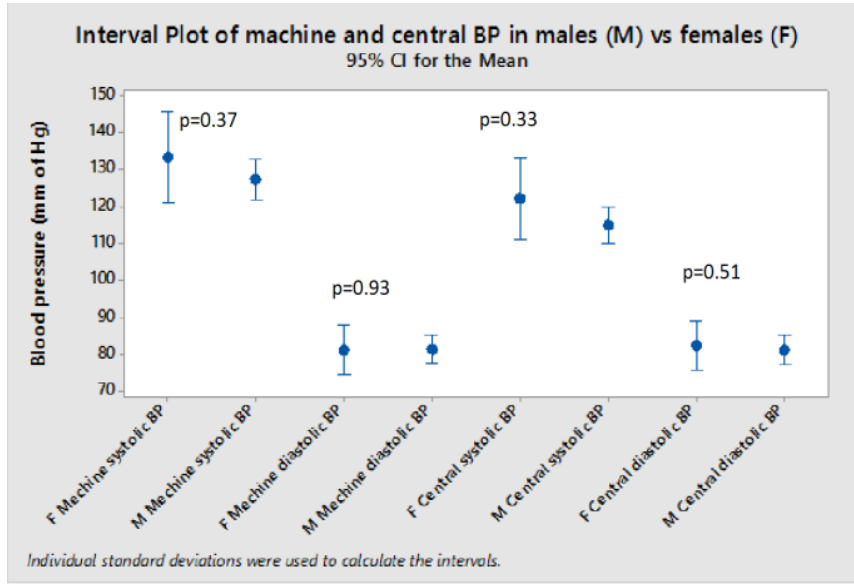

We further analyzed whether there is any gender difference between the blood pressures of machine and manual records. There is no statistically significant difference in the central and peripheral SBP and DBP recorded by the device among males and females as shown in Table 4. Interval plot for difference in the machine derived blood pressure in males and females was drawn as shown in Fig 4.

Fig 4: Interval plot of machine derived central and recorded peripheral blood pressure in males and females.

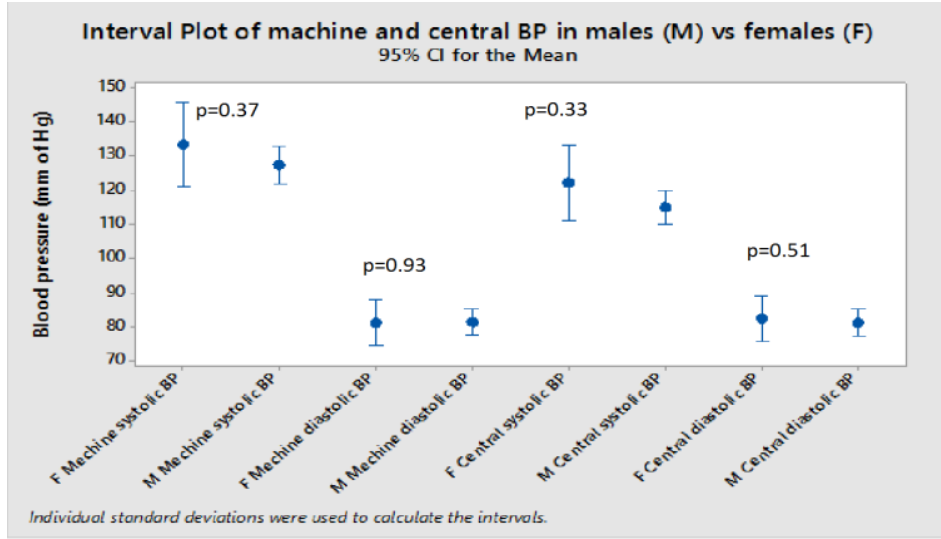


This shows that there is no difference in machine derived values between genders. The device derived parameters including cardiac output, pulse wave velocity, cardiac index, stroke volume, heart rate also did not show significant difference in both sexes. The $p$ value for the machine derived parameters for males and females is shown in table 4 and the difference in BP recordings was shown in table 5.

Table 4: Machine derived parameters in males and females.

\begin{tabular}{|l|l|l|l|}
\hline variable & Female & Male & $\mathrm{p}$ value \\
\hline Age $(\mathrm{Yrs})$ & $58.40 \pm 7.74$ & $59.2 \pm 12.0$ & 0.8 \\
\hline Heart Rate $(\mathrm{bpm})$ & $80.3 \pm 16.3$ & $79.5 \pm 14.8$ & 0.9 \\
\hline $\mathrm{PWV}(\mathrm{m} / \mathrm{s})$ & $8.37 \pm 1.84$ & $8.37 \pm 1.84$ & 0.9 \\
\hline MAP $\{\mathrm{mm} \mathrm{Hg}\}$ & $105.8 \pm 7.8$ & $100.5 \pm 15.4$ & 0.3 \\
\hline $\begin{array}{l}\text { Pulse pressure }(\mathrm{mm} \\
\text { Hg }\end{array}$ & $52.7 \pm 18.8$ & $44.0 \pm 12.7$ & 0.06 \\
\hline $\begin{array}{l}\text { Cardiac Output } \\
(\mathrm{l} / \mathrm{min})\end{array}$ & $4.38 \pm 0.89$ & $4.19 \pm 0.92$ & 0.4 \\
\hline $\begin{array}{l}\text { Stroke } \\
\text { Volume(ml/beat) }\end{array}$ & $54.51 \pm 9.99$ & $54.49 \pm 9.05$ & 0.9 \\
\hline $\begin{array}{l}\text { Cardiac } \\
\text { Index }(\mathrm{l} / \mathrm{min} / \mathrm{m} 2)\end{array}$ & $2.75 \pm 0.47$ & $2.41 \pm 0.59$ & 0.01 \\
\hline
\end{tabular}

Table 5: Comparison of machine derived BP in Males and females.

\begin{tabular}{|l|l|l|l|}
\hline Variable & Female & Male & $\begin{array}{l}\mathrm{p} \\
\text { value }\end{array}$ \\
\hline $\begin{array}{l}\text { Machine Systolic BP } \\
\text { (mm of Hg) }\end{array}$ & $133.5 \pm 6.6$ & $127.5 \pm 18.3$ & 0.4 \\
\hline $\begin{array}{l}\text { Machine Diastolic BP } \\
\text { (mm of Hg) }\end{array}$ & $81.3 \pm 14.0$ & $81.7 \pm 12.4$ & 0.9 \\
\hline $\begin{array}{l}\text { Central Systolic BP } \\
\text { (mm of Hg) }\end{array}$ & $122.3 \pm 23.4$ & $115.1 \pm 16.6$ & 0.2 \\
\hline $\begin{array}{l}\text { Central Diastolic BP } \\
\text { (mm of Hg) }\end{array}$ & $82.5 \pm 14.1$ & $81.3 \pm 12.7$ & 0.7 \\
\hline $\begin{array}{l}\text { Manual Systolic BP } \\
\text { (mm of Hg) }\end{array}$ & $134.5 \pm 25.0$ & $123.9 \pm 16.3$ & 0.09 \\
\hline $\begin{array}{l}\text { Manual Diastolic } \\
\text { BP(mm of Hg) }\end{array}$ & $81.50 \pm$ & $78.21 \pm 8.68$ & 0.2 \\
\hline $\begin{array}{l}\text { Difference Central } \\
\text { systolic }\end{array}$ & $-12.2 \pm 3.8$ & $-8.8 \pm 10.0$ & 0.3 \\
\hline $\begin{array}{l}\text { Difference Diastolic } \\
\text { systolic }\end{array}$ & $1.0 \pm 11.4$ & $3.1 \pm 11.5$ & 0.5 \\
\hline
\end{tabular}

There was no statistically significant difference in these recordings in males and females.

\section{DISCUSSION:}

The heart, kidneys and major arteries supplying the brain are exposed to aortic rather than brachial pressure. Therefore, there is a strong rationale to believe that cardiovascular events may ultimately be more closely related to central rather than brachial pressure. Even in those deemed to be healthy, there was a significant, and highly variable, difference between aortic and brachial systolic pressure at all ages. Moreover, when individuals were stratified by brachial artery blood pressure there was a considerable overlap in aortic systolic pressure, such that over $70 \%$ of individuals categorized as having 'high-normal' brachial systolic pressure based on Joint European Cardiology and Hypertension Society guidelines ${ }^{11}$ had similar aortic pressures to those with stage 1 hypertension. Moreover, .30\% of males and $10 \%$ of females with normal brachial blood pressure had aortic pressures in common with individuals with stage 1 hypertension.

Evidence published over the last 12 years concerning the relationship between central pressure and both surrogate markers of risk and hard endpoints strongly support this concept [12]. Central pressure is more closely correlated with widely accepted surrogate measures of cardiovascular risk such as carotid intima media thickness (CIMT) and left ventricular mass (LVM), $[13,14,15]$, than brachial pressure in crosssectional studies. In the REASON Study,[16] regression of LVM was more strongly related to change in central compared with brachial pressure and, after adjustment, only central pressure remained predictive. Similar observations were made in a sub study of ASCOT. A recent meta-analysis did confirm the independent predictive value of central pressure, and suggested that central pulse pressure may be a better predictor [17]. So the assessment of central aortic pressure is vital and control of central aortic pressure is all that required to reduce the $\mathrm{CV}$ events.

Until relatively recently, it was widely believed that blood pressure reduction per se, matters more than the choice of anti-hypertensive agent [18] However, the results of two comprehensive meta-analyses, $[19,20]$ together with large comparison studies including the MRC-Elderly, [21] LIFE, [22] and ASCOT [23] trials, all demonstrate that the beta-blocker, atenolol, is inferior to 
other major anti-hypertensive drug classes in preventing cardiovascular events. Interestingly, there is now convincing evidence that beta-blockers exert differential effects on brachial vs. central pressure. Such evidence may help to explain the adverse findings with atenolol in outcome studies and provides support for the hypothesis that drugs which lower central pressure the most will be more effective. So the choice of antihypertensive drug also matters as central aortic pressure is targeted.

In the present study, the role of the device in noninvasive central aortic pressure measurement in comparison with conventional method is studied. The results showed that systolic central aortic pressure is less than peripheral systolic pressure. There is no much difference in diastolic BP. The device derived peripheral BP correlated with the conventional method showing its accuracy. The machine derived values are consistent in both genders. So the new device can be used on regular basis in the OPD for calculating the central aortic pressure and target the central aortic rather than the peripheral blood pressure.

\section{Limitations:}

1. The sample size is small and perhaps a study on large population may further clarify the issue

2. The present study is not a follow-up study and incidence of end organ damage by targeting the central aortic pressure is not known.

\section{CONCLUSION:}

Non-invasive central aortic pressure measurement using the device is a simple, can be done in OPD and is lower than peripheral SBP and is a good correlate for CV events. The device derived peripheral BP measurement showed good correlation with conventional measurement. There is no gender difference in the estimation of these pressures by the device and can be used reliably in varied groups of patients.

\section{REFERENCES:}

1. A comparative risk assessment of burden of disease and injury attributable to 67 risk factors and risk factor clusters in 21 regions, 1990-2010: a systematic analysis for the Global Burden of Disease Study 2010. Lancet 2012; 380:2224-2260.

2. Turnbull F, Effects of different blood-pressurelowering regimens on major cardiovascular events: results of prospectively-designed overviews of randomized trials. Lancet 2003; 362:1527-1535.
3. Roman MJ, Devereux RB, Kizer JR, Lee ET, Galloway JM, Ali T, Umans JG, HowardBV. Central pressure more strongly relates to vascular disease and outcome than does brachial pressure: the Strong Heart Study. Hypertension 2007; 50:197-203.

4. Safar ME, Blacher J, Pannier B, Guerin AP, Marchais SJ, Guyonvarc'h PM, London GM.Central pulse pressure and mortality in end-stage renal disease. Hypertension 2002; 39:735-738.

5. Pini R, Cavallini MC, Palmieri V, Marchionni N, Di Bari M, Devereux RB, Masotti G, Roman MJ. Central but not brachial blood pressure predicts cardiovascular events in an unselected geriatric population: the ICAReDicomano Study. J Am CollCardiol 2008;51:24322439

6. Jankowski P, Kawecka-Jaszcz K, Czarnecka D, Brzozowska-Kiszka M, Styczkiewicz K, Loster M, KlchBadelek M, Wilinski J, Curylo AM, Dudek D. Pulsatile but not steady component of blood pressure predicts cardiovascular events in coronary patients. Hypertension 2008; 51:848-855.

7.KroekerEJ,WoodEH.Comparisonofsimultaneouslyreco rdedcentralandperipheral arterial pressure pulses during rest, exercise and tilted position in man. Circ Res 1955;3:623-632.

8. Pauca AL, O'Rourke MF, Kon ND. Prospective evaluation of a method for estimating ascending aortic pressure from the radial artery pressure waveform. Hypertension 2001; 38:932-937.

9. Ohte N, Saeki T, Miyabe H, Sakata S, Mukai S, Hayano J, Niki K, Sugawara M, Kimura G. Relationship between blood pressure obtained from the upper arm with a cuff-type sphygmomanometer and central blood pressure measured with a catheter-tipped micromanometer. Heart Vessels 2007;22:410-415

10. McEniery CM, Yasmin, McDonnell B, Munnery M, Wallace SM, Rowe CV, Cockcroft JR, Wilkinson IB. Central pressure: variability and impact of cardiovascular risk factors: the Anglo-Cardiff Collaborative Trial II. Hypertension 2008;51: 1476-1482 11. Mancia G, De Backer G, Dominiczak A, Cifkova R, Fagard R, Germano G, Grassi G, Heagerty AM, Kjeldsen 
SE, Laurent S, Narkiewicz K, Ruilope L, Rynkiewicz A, Schmieder RE, StruijkerBoudier HA, Zanchetti A. 2007 ESH-ESC Guidelines for the management of arterial hypertension: the task force for the management of arterial hypertension of the European Society of Hypertension (ESH) and of the European Society of Cardiology (ESC). Blood Press 2007;16:135-232

12. Laurent $S$, Cockcroft JR, van Bortel LM, Boutouyrie P, Giannattasio C, Hayoz D, Pannier B, Vlachopoulos C, Wilkinson IB, StruijkerBoudier HA. Abridged version of the expert consensus document. Artery Res 2007;1:2-12

13. Wang KL, Cheng HM, Chuang SY, Spurgeon HA, Ting CT, Lakatta EG, Yin FC, Chou P, Chen CH. Central or peripheral systolic or pulse pressure: which best relates to target organs and future mortality?. J Hypertens 2009;27:461-467.

14. Roman MJ, Okin PM, Kizer JR, Lee ET, Howard BV, Devereux RB. Relations of central and brachial blood pressure to left ventricular hypertrophy and geometry: the Strong Heart Study. J Hypertens 2010;28:384-388

15. Covic A, Goldsmith DJ, Panaghiu L, Covic M, Sedor J. Analysis of the effect of hemodialysis on peripheral and central arterial pressure waveforms. Kidney Int 2000;57: 2634-2643.

16. De Luca N, Asmar RG, London GM, O'Rourke MF, Safar ME.Selective reduction of cardiac mass and central blood pressure on low-dose combination perindopril/ indapamide in hypertensive subjects. J Hypertens 2004;22:1623-1630.

17. Roman MJ, Devereux RB, Kizer JR, Okin PM, Lee ET, Wang W, Umans JG, Calhoun D, Howard BV. High central pulse pressure is independently associated with adverse cardiovascular outcome the strong heart study. J Am CollCardiol 2009;54:1730-1734

18. Major outcomes in high-risk hypertensive patients randomized to angiotensin converting enzyme inhibitor orcalcium channel blocker vs diuretic: The Antihypertensive and Lipid-Lowering Treatment to Prevent Heart Attack Trial (ALLHAT). JAMA 2002; 288:2981-2997.
19. Carlberg B, Samuelsson O, Lindholm LH. Atenolol in hypertension: is it a wise choice? Lancet 2004;364:1684-1689.

20. Lindholm LH, Carlberg B, Samuelsson O. Should beta blockers remain first choice in the treatment of primary hypertension?.A Meta-Analysis. Lancet 2005;366: 1545-1553.

21. Medical Research Council trial of treatment of hypertension in older adults: principal results. MRC Working Party. BMJ 1992;304:405-412.

22. Dahlof B, Devereux RB, Kjeldsen SE, Julius $S$, Beevers G, Faire U, Fyhrquist F, Ibsen H, Kristiansson K, Lederballe-Pedersen O, Lindholm LH, Nieminen MS, Omvik P, Oparil S, Wedel H. Cardiovascular morbidity and mortality in the Losartan Intervention For Endpoint reduction in hypertension study (LIFE): a randomized trial against atenolol. Lancet 2002;359:995-1003.

23. Dahlof B, Sever PS, Poulter NR, Wedel H, Beevers DG, Caulfield M, Collins R, Kjeldsen SE, Kristinsson A, McInnes GT, Mehlsen J, Nieminen M, O'Brien E, Ostergren J. Prevention of cardiovascular events with an antihypertensive regimen of amlodipine adding perindopril as required versus atenolol adding bendroflumethiazide as required, in the AngloScandinavian Cardiac Outcomes TrialBlood Pressure Lowering Arm (ASCOT-BPLA): a multicentrerandomized controlled trial. Lancet 2005;366:895-906.

24. Carmel M. McEniery, John R. Cockcroft, Mary J. Roman, Stanley S. Franklin, and Ian B. Wilkinson. Central blood pressure: current evidence and clinical importance. European Heart Journal (2014) 35, 17191725 doi:10.1093/eurheartj/eht565.

25. Pickering T, Hall J, Appel L, Falkner B, Graves J, Hill $\mathrm{M}$ et al. Recommendations for Blood Pressure Measurement in Humans and Experimental Animals: Part 1: Blood Pressure Measurement in Humans: A Statement for Professionals From the Subcommittee of Professional and Public Education of the American Heart Association Council on High Blood Pressure Research. 2017. 